\title{
FAKTOR-FAKTOR YANG MEMPENGARUHI PRODUKSI USAHA TERNAK BABI DI TELUK DORERI KABUPATEN MANOKWARI
}

\section{FACTORS AFFECTING THE PRODUCTION OF PIGS IN THE BAY DORERI MANOKWARI DISTRICT}

\author{
Trisiwi Wahyu Widayati ${ }^{1)}$, Iriani Sumpe ${ }^{1)}$, Bernadeta Wahyuni Irianti ${ }^{1)}$, Denny \\ Angelus Iyai ${ }^{1)}$, dan Sangle Yohanes Randa ${ }^{1)}$ \\ 1) Fakultas Peternakan, Universitas Papua Manokwari Indonesia \\ Email: t.widayati@unipa.ac.id
}

\begin{abstract}
ABSTRAK
Studi ini bertujuan untuk menentukan faktor-faktor yang berpengaruh terhadap produktivitas usaha ternak babi di Teluk Doreri, Manokwari Papua Barat. Data diambil dari 33 peternak babi yang bermukim di sekitar Teluk Doreri, Manokwari. Data yang dikumpulkan berupa data primer, antara lain karakterisktik petani, terdiri dari umur, pendidikan, pengalaman beternak babi, dan data terkait dengan produksi usaha ternak babi, antara lain jumlah dan tipe pakan sumber energi dan protein, jumlah induk yang dimiliki peternak, bobot badan rata-rata induk babi, dan lahan yang dimiliki peternak untuk usaha ternak babi. Hasil penelitian menunjukkan bahwa jumlah pakan sumber energi dan protein, curahan waktu kerja peternak, bobot induk babi dan lahan yang dimiliki petani untuk usaha ternak babi berpengaruh positif terhadap produksi ternak babi di Teluk Doreri, Manokwari. Faktor-faktor penentu produksi tersebut dapat dijadikan sebagai bagian penting untuk meningkatkan produksi usaha ternak babi di Teluk Doreri, Manokwari.
\end{abstract}

Kata Kunci : Manokwari, Papua Barat, produksi, Teluk Doreri, usaha ternak babi

\begin{abstract}
This study aims to determine the factors that affect the productivity of pig business in Doreri Bay, Manokwari West Papua. Data were taken from 33 pig farmers living around Doreri Bay, Manokwari. The data collected are primary data, such as the characteristics of the farmer, consisting of age, education, experience of raising pigs, and in the form of data related to the production of pig business, such as the number and types of feed sources of energy and protein, the number of mains owned by farmers, the weight of the average pig breeder, and the land owned by the breeder for the pig business. The results showed that the amount of feed source of energy and protein, the time spent by the farmers to raise pigs, the weight of mother of pig and the land owned by the farmers for the pigs business had a positive effect on the production of pigs in Doreri Bay, Manokwari. It is known that the determinants of production can be used as an important and important part to increase the production of pig business in Teluk Doreri, Manokwari.
\end{abstract}

Keywords : Doreri Gulf, Manokwari, production, Pig Business, West Papua 


\section{PENDAHULUAN}

Indonesia yang merupakan Negara kepulauan yang dihuni oleh penduduk yang mayoritas tinggal di pedesaan dan menggantungkan hidupnya pada sektor primer khususnya pertanian. Peran sektor pertanian dalam perekonomian Indonesia secara umum adalah: (1) pembentuk Produk Domestik Bruto (PDB); (2) salah satu sumber penghasil devisa; (3) penyedia pangan penduduk dan bahan baku bagi industri; (4) salah satu sektor yang dapat mengentaskan masalah kemiskinan; (5) penyedia lapangan kerja; (6) salah satu sumber peningkatan pendapatan masya rakat; dan (7) salah satu sumber pemantapan ketahanan pangan nasional (Hafzrianda, et al., 2012).

Kontribusi sektor pertanian di Kabupaten Jayawijaya sebesar 10,46 persen dan 2,96 persen yaitu sub sektor tanaman bahan makanan dan sub sektor peternakan. Sedangkan sub sektor lainnya hanya mampu memberikan kontribusinya sebesar 0,14 persen. Sektor yang perlu dikembangkan pada sektor pertanian hanya ada dua sub sektor saja yaitu sub sektor tanaman bahan makanan dan sub sektor peternakan (Hafzrianda, et al., 2012).

Produk Domistik Regional Bruto (PDRB) asal ternak di Provinsi Papua Barat atas dasar harga konstan pada kurun waktu 2013 sampai dengan 2015 meningkat sebesar $11 \%$. Hal ini menunjukkan bahwa sub-sektor peterna kan merupakan sub-sektor yang cukup prospektif menjadi sarana untuk meningkatkan pendapatan masyarakat. Usaha peternakan yang umumnya diusahakan oleh masyarakat Papua Barat adalah ternak babi dan ternak sapi, sehingga dua instrumen inilah yang dapat menjadi alat bagi Pemerintah untuk melakukan pemberdayaan masyarakat, namun demikian ternak babi jauh lebih menjadi pilihan bagi masyarakat Papua dibanding ternak sapi (Anonimous, 2016).

Pembangunan peternakan meru pakan bagian integral dari tujuan utama pembangunan pertanian untuk mening katkan pendapatan dan kesejahteraan masyarakat dalam mewujudkan tujuan pembangunan nasional. Ternak babi mendominasi ternak besar di Papua Barat. Pada tahun 2013 ternak babi menempati urutan kedua setelah ternak 
sapi potong. Jumlah ternak babi 53.440 ekor, kambing 10.384 ekor, sapi potong 47.642 ekor. Sementara itu taun 2006 produksi daging sapi $389,290 \mathrm{~kg}$ dan daging babi tahun 2006 sebesar 179,440 $\mathrm{kg}$.

Ternak babi bagi masyarakat Papua dari sejak nenek moyang sampai sekarang tidak pernah punah. Secara umum bagi masyarakat Papua, ternak babi banyak digunakan dalam pembayaran maskawin, denda (perzinahan, pencurian, pembunuhan) dan juga upacara-upacara adat dan harihari besar ritual keagamaan. Iyai, et al., (2011) menyatakan bahwa nilai ternak babi sangat tinggi karena erat kaitannya dengan praktek adat istiadat dan upacara ritual budaya setempat. Ternak babi sering digunakan dalam berbagai kegiatan budaya, termasuk untuk maskawin dan sebagai alat tukar. Jumlah babi yang dimiliki biasanya dijadikan sebagai ukuran status seseorang, semakin banyak ternak babi yang dimiliki, berarti semakin tingginya status sosial dalam kehidupan bermasyarakat di Papua.

Sumber daya alam di Papua sangat potensial untuk pengembangan usaha ternak babi. Menurut laporan hasil studi Patisselano dan Iyai (2005), pakan yang biasa diberikan untuk ternak babi di Kota Manokwari adalah limbah rumah makan, sisa sayursayuran, kulit pisang, singkong, ampas tahu, limbah pasar ikan dan sisa dapur sebagai pakan ternak. Pada daerah perkampungan dan luar kota, ternak babi umumnya diberi pakan berupa ubiubian, batang pisang, dan kelapa (Iyai et al, 2011).

Pengembangan suatu usaha ternak yang baik adalah pengembangan usaha ternak yang disesuaikan dengan potensi daerah, ketersediaan pakan, kondisi sosial budaya dan iklim setempat guna meningkatkan produk tivitas ternak yang berdaya saing (Jabbar and Akter, 2008; Babovic, et al., 2011). Sistem produksi ternak yang berdaya saing haruslah didasarkan pada keuntungan komparatif dengan meman faatkan sumber daya lokal, termasuk pula pakan maupun limbah pertanian.

Kabupaten Manokwari memiliki potensi yang baik untuk mengem bangkan ternak babi. Potensi tersebut apabila dikelola dan dimanfaatkan secara optimal untuk memenuhi 
kebutuhan ternak terutama untuk peternakan rakyat yang ada di sekitar kawasan pesisir Teluk Doreri maka kemingkinan besar keberhasilan dapat tercapai. Banyak faktor yang mempe ngaruhi keberhasilan peternak dalam mengelola ternak-ternaknya, diantara nya adalah keadaan peternak itu sendiri, baik dalam hal pengetahuan tentang budidaya ternak, sosial ekonomi dan budaya dan keadaan rumah tangga. Halhal ini menjadi indikator yang penting untuk diperhatikan.

\section{BAHAN DAN METODE}

Penelitian ini dilaksanakan di Pesisir Teluk Doreri, Kabupaten Manokwari. Pemilihan lokasi dilakukan secara purposif didasarkan pada keadaan ternak babi yang ada. Sampel peternak yang diambil sebanyak 33 rumah tangga peternak babi yaitu para peternak yang sudah memproduksi ternak babi atau sudah pernah menjual ternak babi. Data diperoleh melalui wawancara dan pengisian kuisoner. Data yang dimaksud meliputi : a. Karak teristik petani dan rumah tangganya, antara lain nama petani, umur, pendidi kan formal, dan b. data-data yang berhubungan dengan kegiatan produksi ternak babi, antara lain jumlah induk yang dipelihara, jumlah dan jenis pakan yang digunakan, permodalan serta sumber nya, dan tenaga kerja yang dipergu nakan. Data yang diperoleh ditabulasi dan dianalisis menggunakan regresi berganda metode Ordinary Least Square dengan dengan bantuan Eviews 5.0 .

\section{Analisis Data}

Untuk melihat bagaimana sistem produksi beternak babi yang dilakukan oleh masyarakat di Kabupaten Manok wari, maka dalam penelitian ini dilaku kan pendekatan dengan menganalisis profil sistem produksi ternak babi. Profil sistem ternak babi dianalisis dengan me lihat hubungan antara produksi ternak babi pembibitan dengan faktor-faktor yang mempengarui dengan mengguna kan persamaan regresi sebagai berikut. Ln Produksi $=\ln$ ao $+\mathrm{a}_{1} \ln$ PSE $+\mathrm{a}_{2} \ln$ $\mathrm{PSP}+\mathrm{a}_{3} \ln \mathrm{JLI}+\mathrm{a}_{4} \ln \mathrm{TK}$ $+\mathrm{a}_{5} \ln \mathrm{CK}+\mathrm{a}_{6} \ln \mathrm{UP}+\mathrm{a}_{7}$ ln Pengalaman+ $\mathrm{a}_{8} \ln \mathrm{BI}+$ a 9 In Pddkn + $\mathrm{a}_{10} \ln$ Lahan $+\varepsilon$ 
Keterangan :

Produksi : jumlah anak babi lepas sapih dengan berat badan anak babi lepas sapih yang dihasilkan dari usaha pembibitan babi $(\mathrm{kg})$

$\mathrm{a}_{\mathrm{o}} \quad$ : Intersept

$\mathrm{a}_{\mathrm{i}} \quad$ : Koefisien regresi (parameter yang ditaksir $)(\mathrm{i}=1 \mathrm{~s} / \mathrm{d} 10)$

PSE : Pakan Sumber Energi yang diberikan selama proses produksi $(\mathrm{kg})$

PSP : Pakan Sumber Protein yang diberikan selama proses produksi $(\mathrm{kg})$

JLI : Jumlah Induk yang dimiliki peternak (ekor)

TK : Jumlah tenaga kerja yang digunakan dalam usaha (orang)

CK : Curahan waktu kerja (jam/hari)

BI : Bobot badan induk (kg)

UP : Umur peternak (Tahun)

Pddkn : Pendidikan Peternak (Tahun)

dimana Tamat $\mathrm{SD}=6$, Tamat $\mathrm{SMP}=9$, Tamat $\mathrm{SMA}=12$

Kuliah $=17$

Lahan : Lahan yang digunakan untuk usaha peternakan babi

$\varepsilon \quad$ : error term

\section{HASIL DAN PEMBAHASAN}

Hasil analisis (Tabel 1) menunjukkan bahwa faktor-faktor yang mempengauhi produksi usaha ternak babi di Pesisir Teluk Doreri Kabupaten Manokwari dengan nilai $\mathrm{R}^{2}=0.914$, artinya model produksi ternak babi di pesisir Teluk Doreri dapat dijelaskan oleh variabel-variabel independen, antara lain : a. pakan sumber energi, b. pakan sumber protein, c. curahan waktu kerja, d. bobot induk dan lahan sebesar $91,40 \%$, sedangkan sisanya sebesar $8,60 \%$ dipengaruhi oleh faktor-faktor diluar model.

Produksi ternak babi merupakan perkalian antara jumlah anak babi lepas sapih dengan berat badan anak babi lepas sapih yang dihasilkan dari usaha pembibitan babi di Manokwari. Dari hasil analisis secara parsial menunjuk kan bahwa pakan sumber energi, pakan sumber protein, curahan waktu kerja, bobot induk dan luasan lahan yang dimiliki peternak untuk usaha, berpengaruh positif terhadap produksi 
babi pada usaha peternakan babi di Teluk Doreri, Kabupaten Manokwari.

Pakan sumber energi berpenga ruh positif terhadap produksi babi dengan elastisitas $0.435(\alpha=10 \%)$. Pakan sumber energi merupakan faktor penting yang harus diperhatikan dalam kegiatan produksi ternak babi. Kecukupan pakan, baik secara kualitas maupun kuantitas akan menentukan keberhasilan produksi dan reproduksi ternak babi. Menurut Velayudan. et al., (2015), pakan sumber energi dibutuhkan ternak babi untuk fungsi pemeliharaan dan produksi. Termasuk dalam fungsi pemeliharaan adalah metabolism basal, aktivitas otot pencernaan, sirkulasi darah dan penggantian jaringan. Menurut Sihombing (2016) pakan yang merupakan sumber energi pada ternak babi antara lain adalah biji-bijian (jagung, gandum, sorgum), dari hasil sampingan seralia (limbah penggili ngan) dan kelompok umbi-umbian (singkong, keladi, betatas). Di pesisir Teluk Doreri sebagian peternak memiliki lahan kebun sendiri sehingga mudah mendapatkan pakan sumber energi bagi ternak babi mereka.
Pakan sumber protein dapat meningkatkan produksi ternak babi dengan elastisitas $0.179(\alpha=10 \%)$. Tilman (1999) menyatakan bahwa pakan yang dapat dikategorikan sebagai sumber protein adalah pakan yang memiliki kandungan protein di atas 20\%. Bahan makanan yang pada umumnya diperlukan untuk memenuhi kebutuhan protein pada ternak babi ialah tepung ikan dan bungkil kedelai. Menurut Sihombing (2006), ternak babi sangat membutukan protein karena fungsi protein sebagai pembentuk selsel atau jaringan tubuh (misalnya pada pertumbuhan anak dan babi muda), menggantikan sel-sel rusak (misalnya memproduksi air susu). Di Pesisir Teluk Doreri banyak ditemukan limbah ikan, namun para peternak lebih banyak menggunakan ampas tahu sebagai pakan sumber protein untuk ternak babi mereka. Hal ini sesuai studi dari Hernaman, et al., (2005) yang menyatakan bahwa ampas tahu bisa digunakan sebagai pakan ternak babi. Ditambahkan oleh Stradivari, et al., (2015) bahwa ampas tahu memiliki kandungan protein kasar 22,1\% dan 
sangat baik digunakan sebagai sumber protein untuk ternak babi.

Tabel 1. Faktor-Faktor Penentu Produksi Babi di Teluk Doreri, Kabupaten Manokwari

\begin{tabular}{lcrrrr}
\hline Variabel & TH & Koefesien & Std. Error & t-Statistic & Prob. \\
\hline Pakan Sumber Energi (kg) & + & $0.435^{*}$ & 0.240 & 1.811 & 0.084 \\
Pakan Sumber Protein (kg) & + & $0.179^{*}$ & 0.096 & 1.867 & 0.075 \\
Jumlah Induk (ekor) & + & -0.062 -ts & 0.109 & -0.572 & 0.573 \\
Tenaga Kerja & + & $0.127-$ ts & 0.168 & 0.759 & 0.456 \\
Waktu Kerja & + & $0.272^{*}$ & 0.154 & 1.762 & 0.092 \\
Umur Petani & + & $-0.068-$ ts & 0.149 & -0.453 & 0.655 \\
Pengalaman & + & $0.124-$ ts & 0.096 & 1.280 & 0.214 \\
Bobot Induk & + & $0.803^{*}$ & 0.413 & 1.941 & 0.065 \\
Pendidikan & + & $-0.045-$-ts & 0.059 & -0.764 & 0.453 \\
Lahan & + & $0.154^{* *}$ & 0.068 & 2.267 & 0.034 \\
Constanta & & -1.613 & 1.722 & -0.937 & 0.359 \\
\hline R-squared & & 0.914 & F-statistic & & 23,346 \\
Adjusted R-squared & & 0.875 & Prob(F-statistic) & & 0,000 \\
\hline
\end{tabular}

$\begin{array}{ll}\text { Keterangan : } & \\ * & : \text { signifikan pada taraf kepercayaan } 90 \% \\ * * & : \text { signifikan pada taraf kepercayaan } 95 \% \\ \text { ts } & : \text { tidak signifikan } \\ \text { th } & : \text { tanda harapan }\end{array}$

Bahan pakan yang paling banyak digunakan sebagai pakan babi di masyarakat Pesisir Teluk Doreri Kabupaten Manokwari adalah ubi-ubian (56,56 \%). Tanaman tersebut diusahakan di lahan yang dimiliki oleh peternak babi. Ubi-ubian termasuk golongan pakan sumber energy maka seharusnya peternak tidak hanya memberikan pakan ubi sebagai pakan tunggal. Dari Tabel 2. tampak bahwa baru $16,67 \%$ peternak menggunakan pakan ampas tahu sebagai sumber protein dalam ransum babi milik mereka. Oleh karena itu perlu bagi pemerintah setempat dalam rangka pemberdayaan dan meningkatkan pengetahuan masyarakat peternak babi 
di Kabupaten Manokwari agar Bahan-bahan pakan yang biasa memberikan pelatihan dan keterampilan digunakan oleh peternak babi di Pesisir pada masyarakat dalam menyediakan Teluk Doreri Kabupaten Manokwari ransum yang memenuhi standard disajikan pada Tabel 2.

kebutuhan gizi bagi ternak babi mereka.

Tabel 2. Distribusi Peternak berdasarkan Penggunaan Bahan Pakan Ternak Babi

\begin{tabular}{clcc}
\hline No. & Jenis pakan & Kepala Keluarga (KK) & Nisbah (\%) \\
\hline 1 & Ubi - Ubian & 18 & 56,67 \\
2 & Limbah rumah tangga & 17 & 50,00 \\
3 & Sayur- sayuran & 12 & 37,67 \\
4 & Limbah Pasar & 7 & 20,00 \\
5 & Ampas tahu & 6 & 16,67 \\
\hline
\end{tabular}

Sumber: Data Primer Tahun 2013

Bobot induk berpengaruh positif terhadap produktivitas usaha ternak babi dengan elastisitas $0.803^{*}(\alpha=10 \%)$. Defra (1998) menjelaskan bahwa kondisi tubuh induk yang nampak pada bobot induk mempunyai pengaruh yang signifikan tehadap kemampuan induk untuk memproduksi susu bagi anakanaknya, sehinga akan berdampak positif pada pertumbuhan bobot hidup anak pada saat lepas sapih.

Curahan waktu kerja peternak berpengaruh positif terhadap produktivitas usaha ternak babi dengan elastisitas $0.272 *(\alpha=10 \%)$. Hal ini sesuai hasil studi Lubis et al (2016) yang menyatakan bahwa banyaknya waktu yang tercurah bagi tenaga kerja dalam usaha peternakan akan berpengaruh positif terhadap produksi dan pendapatannya. Bagi peternak babi di Pesisir Teluk Doreri, waktu yang dicurahkan untuk usaha ternak babi mereka antara lain untuk melakukan kegiatan mencari bahan-bahan pakan untuk babi. Dengan semikian babi lebih mendapatkan perhatian dan tercukupi kebutuhan pakan untuk setiap harinya.

Faktor luasan lahan yang digunakan untuk peternakan babi 
berpengaruh positif terhadap produksi ternak babi pada masyarakat Pesisir Teluk Doreri Kabupaten Manokwari dengan elastisitas $0.154 * *(\alpha=5 \%)$. Hasil ini sesuai pendapat Koirala et al (2016) bahwa lahan merupakan kunci utama dalam usaha pertanian. Demikian pula bagi masyarakat peternak babi di Pesisir Teluk Doreri Kabupaten Manokwari keberadaan lahan sangat menolong peternak tidak saja untuk menjalankan usaha peternakannya namun sekaligus sebagai tempat pasokan pakan bagi ternak babi terutama adalah pakan sumber energi. Sehingga minimal kebutuhan pakan ternak dapat lebih terjamin dibanding para peternak yang kurang memiliki lahan yang cukup.

\section{KESIMPULAN}

Faktor-faktor produksi peternakan babi yang secara positif berpengaruh terhadap produksi peternakan babi di Pesisir Teluk Doreri Manokwari adalah pakan sumber energi, pakan sumber protein, bobot induk babi, curahan waktu kerja dan luas lahan yang dimiliki peternak untuk usaha ternak babi. Untuk mendukung kesuksesan dalam usaha ternak babi perlu peningkatan pengetahuan dan ketrampilan peternak dalam membuat ransum babi yang memiliki kandungan energy dan protein yang memadai.

\section{UCAPAN TERIMAKASIH}

Ucapan terimakasih disampaikan kepada Kementerian Ristek Dikti yang telah membiayai penelitian ini dengan skema Hibah Bersaing dengan nomor kontrak 287.C/UN42/KU/2013.

\section{DAFTAR PUSTAKA}

Babovic J., M. Caric, D. Djordjevic, S. Lazic. 2011. Factors influencing the economic of the pork meat production. Agric. Econ. 57(4): 203-209.

Anonim. 2016. Papua Barat dalam Angka [West Papua in Numbers]. Badan Pusat Statistik Provinsi Papua Barat. BPS. Papua Barat.

Defra. 1998. Condition Scoring of Pigs. Departemen of Environment Food and Rural Affair. Defra Publication.London. http://www. Adlib.everysite.couk/adlib/defra.

Hafzrianda, Y., C.M. Bisai dan A.R. Pajeru. 2012. Analisis Pertumbuhan dan Potensi Sektoral. Pertanian dalam Perekonomian Kabupaten 
Jayawijaya. Tahun 2008 - 2012. diakses 21-5-2018.

Hernaman I., R. Hidayat., Mansyur. 2005. Pengaruh pengunaan Molase dalam Pembuatan Silase Campuran Ampas tahu dan Pucuk Tebu Kering terhadap Nilai $\mathrm{pH}$ dan Komposisi Zat-zat makannannya. Jurnal Ilmu Ternak. Vol 5(2): 94-99.

Iyai, D.A, B.W.I. Rahayu, I. Sumpe, D. Saragih. 2011. Analysis Of Pig Profile on Small-Scale.

Pig Farmer In Monokwari West Papua. Jurnal the Indonesian Tropical Animal. 36(3): 190-196.

Jabbar, M.A., and S. Akter. 2008. Market and other factors affecting farm specific production efficiensi in pig production in Vietnam. Journal of International Food and Agribusiness Marketing. 20(3): 29-53.

Koirala K.H., A. Mishra.,S. Mohanty. 2016. Impact of Land Ownership on Productivity and Efeciency of Rice Farmers. The Case of Philippines. Land Use Policy 50 :371-378.

Lubis Y.R., A. Firman dan H.Ariel. 2016. Analisis Curahan Waktu Kerja dan Pendapatan Keluarga Peternak Sapi Perah. http://jurnal.unpad.ac,id/ejournal/a rticle/download/10268/4681.
Pattiselano, F. 2005. Limbah yang berguna: Harapan peternak babi terhadap sumber pakan alternatif di pesisir Manokwari. [Useful Waste: Pig Farmers' Hope for Feed Source Alternatives in Manokwari's Coastal Region] Majalah Pertanian Berkelanjutan SALAM. No 13:24-25.

Sihombing, D.T.H. 2006. Ilmu Ternak babi. Gadjah mada Press. Yogyakarta.

Stradivari.G.E., K. Budaarsa,W. Puger. 2015. Peternakan Tropika. 3(3): 524-536.

Velayudhan. D.E., I.H. Kim, and C.M. Nyachoti.2015. Characterization of Dietary Energy in swine Feed and Feed Ingredients: A review of Recent Research Results.AsianAustralas J.Anim Sci. 28(1):1-13. 